\title{
Main Drivers of Carbon Dioxide Emissions in Vietnam Trajectory 2000-2011: An Input-Output Structural Decomposition Analysis
}

\author{
Hoa Thi Nguyen ${ }^{1}$, Kathleen B. Aviso ${ }^{2}$, Dien Quang Le $^{3} \&$ Akihiro Tokai ${ }^{1}$ \\ ${ }^{1}$ Division of Sustainable Energy and Environmental Engineering, Osaka University, Japan \\ ${ }^{2}$ Chemical Engineering Department, De La Salle University, Manila, Philippines \\ ${ }^{3}$ Department of Pulp and Paper Industry, School of Engineering, Hanoi University of Science and Technology, \\ Hanoi, Vietnam \\ Correspondence: Hoa Thi Nguyen, Division of Sustainable Energy and Environmental Engineering, Osaka \\ University, Japan. E-mail: Hoa@em.see.eng.osaka-u.ac.jp
}

Received: June 3, 2018

doi:10.5539/jsd.v11n4p129
Accepted: July 1, $2018 \quad$ Online Published: July 29, 2018

URL: https://doi.org/10.5539/jsd.v11n4p129

\begin{abstract}
Vietnam's rapid economic growth has resulted in serious environmental concerns both at local and global scales. In-depth understanding of the key factors behind the rapid growth of $\mathrm{CO}_{2}$ emissions is of great significance in the development of local and global climate policies. Furthermore, this provides insight into how emerging economies can develop a low emission future. Recent works have demonstrated the effectiveness of the inputoutput model and structural decomposition analysis in analyzing how changes in different socio-economic factors affect energy-based $\mathrm{CO}_{2}$ emissions in the sectoral level using production and consumption-based perspectives. In the context of Vietnam's economy, such aspects have not been fully explored in previous literature. This study thus analyzes the driving forces responsible for the increase in $\mathrm{CO}_{2}$ emissions in Vietnam from both production and consumption perspective during periods $2000-2007$ and $2007-2011$. The results using the production perspective indicate that during $2000-2011$ the incremental change in $\mathrm{CO}_{2}$ emissions in Vietnam is driven mainly by the consumption structure $(100.5 \%)$ and consumption volume $(219.4 \%)$ which are offset by the decline in technology (-132.7\%) and production structure (-22.5\%). Population $(24.1 \%)$ had a small effect on total $\mathrm{CO}_{2}$ emissions. Results using the consumption perspective show that even with large variations between the two periods, household, export and investment are the main drivers responsible for the sharp increase in $\mathrm{CO}_{2}$ emissions. This is offset by the decrease in import factor. Policy implications indicate that improving technology, adjusting production and consumption structure, and optimizing international trade are important factors for alleviating $\mathrm{CO}_{2}$ emissions in Vietnam.
\end{abstract}

Keywords: input-output analysis, structural decomposition analysis, driving forces, $\mathrm{CO}_{2}$ emissions, Vietnam

\section{Introduction}

The impact of economic production activities on the environment has caused serious global problems such as global warming. Rising greenhouse gas (GHG) emissions, mainly $\mathrm{CO}_{2}$ generation, from the continued consumption of fossil fuels remains a main contributor to global warming which has induced climate change. The World Bank (2010) reported that if anthropogenic activities continue to operate at usual conditions, this could result in a $5{ }^{\circ} \mathrm{C}$ increase in global temperature but timely and appropriate intervention may limit it within $2{ }^{\circ} \mathrm{C}$. Thus, reducing GHG releases has become an emerging economic development research interest world-wide (Wang, Yin, Zhang, \& Zhang, 2012).

Currently, Vietnam is in the last process of rapid industrialization and is expected to pass into an innovative stage of development (Maryzin, 2013). Since 2000, the Vietnamese economy has positively prospered with annual economic growth rates up to above 5\% (PricewaterhouseCoopers, 2017). This rapid economic growth was accompanied by increased energy consumption (MNRE, 2014) and resulted in corresponding increases in GHG emissions from the energy sector. N. Nguyen, Ha-Duong, \& Sandra (2009) reported that the projection of GHG generation from energy combustion will increase tremendously by up to $14 \%$ per year, reaching nearly 400 million tonnes of $\mathrm{CO}_{2}$ in 2030. In order to mitigate the impact of climate change, the $1992 \mathrm{UN}$ Framework Convention on Climate Change (UNFCCC) developed the Kyoto Protocol which required member countries to 
promote environmental policies to reduce GHG emissions (UNFCCC, 1998). As a non-annex I country under Kyoto Protocol, Vietnam is not required to abate GHG emissions. It has however ratified the agreement to pursue efforts of reducing emissions in polluting sectors such as the energy, agriculture and transportation sectors (KEPA \& GreenID, 2014). In light of this, Vietnam submitted an intended nationally determined contribution (INDC) to the 2015 United Nations Climate Change Conference (COP21), which commits to a $25 \%$ reduction in GHG emissions by 2030 compared to the business-as-usual (BAU) levels (UNFCCC, 2015a; 2015b). H. Nguyen, Aviso, Le, Kojima, \& Tokai (2018b) employed a high-level assessment of the potential effectiveness of mitigating GHG emissions by considering low-carbon measures including differentiated growth of sectors, shift to low-carbon energy mix, broad deployment of energy conservation measures for final consumption and use of low-carbon technologies in agriculture, transport and waste sectors. The results indicate that the targets of GHG emissions outlined in INDC are achievable if all the strategies outlined are implemented altogether. However, according to KEPA and GreenID (2014), in addition to technology factor and annual growth, there are many other socio-economic factors which impact the incremental changes in GHG emissions of an economy. In-depth understanding of these drivers may help in developing short-term and long-term sustainable energy emission mitigation strategies. In Vietnam, the main contributor to total GHG emissions is $\mathrm{CO}_{2}$, which accounts for $48 \%$ (H. Nguyen et al., 2018b; MNRE, 2014) of the total. Thus, the effectiveness of GHG mitigation measures can be enhanced and maximized if the main drivers of $\mathrm{CO}_{2}$ generation can be identified. In other words, uncovering these main drivers could be helpful in reaching reduction targets and projecting future low-emission scenarios (Shahiduzzaman \& Layton, 2017; Guan, Hubacek, Weber, Peters, \& Reiner, 2008).

Cansino, Roman, \& Ordóñez (2016) indicated that decomposition analysis facilitates the identification of driving forces which are more crucial for mitigating $\mathrm{CO}_{2}$ emissions. Liu and Wang (2013) proved that using decomposition method allows for the analysis of how different factors contribute to the changes of $\mathrm{SO}_{2}$ emissions. Frequently used methods of decomposition analysis include the LMDI method (Shrestha, Anandarajah, \& Liyanage, 2009; Cansino, Sánchez-Braza, \& Rodríguez-Arévalo, 2015; Chen, Li, Zhou, Yang, \& Chen, 2017), the IPCC method (IPCC, 2006), and the SIRPAT method (Fu et al. 2015; Shuai, Shen, Jiao, Wu, \& Tan, 2017). Recently, the Kaya Index method was used for identifying the drivers of $\mathrm{CO}_{2}$ emissions in Vietnam (A. Nguyen, 2012), for linking changes in GHG emissions in Baltic States (Štreimikienè \& Balezentis, 2016), and for identifying the driving forces of $\mathrm{CO}_{2}$ emissions from construction (Mavromatidis, Orehounig, Richner, \& Carmeliet, 2016), to name a few. The advantage of these methods is the ability to examine the various factors which affect energy-based $\mathrm{CO}_{2}$ emissions. They are later used to propose the differentiated measures which should be adopted for each region. However, these previous works have failed to provide a comprehensive analysis of how the connections between the different economic sectors and other economic structure factors affect emissions. To fill this gap, a hybrid input-output structural decomposition analysis (IO-SDA) method using economic input-output tables is applied to provide a more detailed assessment of economic structure changes over time (Xie, 2014). Furthermore, IO-SDA can show socio-economic factors from both production and consumption perspectives (Casino et al., 2016; Wang, Huang, Yang, \& Yu, 2013). With decomposition on a sectoral scale, IO-SDA can analyze the driving factors for pollutants from high-polluting sectors (Cansino et al., 2016; Wang, Huang, Yu, Hu, \& Xu, 2016)

Rose and Chen's (1991) seminal work using IO-SDA assessed the changes in the sectoral energy use in the U.S. while Rose and Casler (1996) later gave the basic principles to get equations for structural decomposition. A similar approach was implemented for optimizing supply chain network under water footprint constraints (Aviso, Tan, Culaba, \& Cruz, 2011). IO-SDA model has been used successfully not only on a national scale (Huang \& Wu 2013; Koh et al., 2016), but also on a city scale (Wang \& Wang 2015, Wei et al., 2017). IO-SDA was also utilized in analyzing the emissions embodied in trade among countries (Xu \& Dietzenbacher, 2014; Wang, Ang, \& Bin Su, 2017) and in projecting the future emission scenarios (Shahiduzzaman \& Layton, 2017).

There are few studies which have utilized decomposition analysis for analyzing the Vietnamese economy. A. Nguyen (2012) applied the Kaya Index to analyze $\mathrm{CO}_{2}$ emission variability in Vietnam during 1986 - 2008, while Zimmer, Jakob, \& Steckel (2015) used it for the period of 1975-2010. These authors were successful in evaluating the changes in $\mathrm{CO}_{2}$ emissions using a macro-economic scale, but they failed to identify the changes in $\mathrm{CO}_{2}$ emissions at the sectoral scale. T. Nguyen and Ishihara (2006a; 2006b) used IO-SDA to analyze the variation of energy flows in Vietnam from 1989 to 2000. These helped identify the changes in energy flows at the sectoral level, but they focused primarily on energy intensity and lacked analysis of other socio-economic drivers such as production structure, population and consumption structure to name a few. 
To supplement this research gap, this paper used the IO-SDA to analyze the driving forces of $\mathrm{CO}_{2}$ emissions looking at various perspectives over two categorical periods, 2000 - 2007 and 2007 - 2011. In light of this, more recent data on emissions, gross domestic product (GDP), population and IO tables are used in order to achieve the three fold objectives as follows:

1) Decompose the changes in $\mathrm{CO}_{2}$ emissions from the production perspective with five socio-economic driving forces including technology, production structure, consumption structure, consumption volume and population growth.

2) Decompose the changes in $\mathrm{CO}_{2}$ emissions from the consumption (final demand) perspective with different consumption categories including government, household, investment, import and export.

3) Propose policy recommendations for policy makers, manufacturers and relevant partners for reducing $\mathrm{CO}_{2}$ emissions.

The rest of paper is organized as follows. The methodology is discussed in Section 2. Section 3 shows the dataset used. Results, discussion and policy implications are then mentioned in Section 4. Finally, conclusions and recommendations for future work are presented in Section 5.

\section{Methods}

The framework developed to achieve the objectives of the study is illustrated in Figure 1:

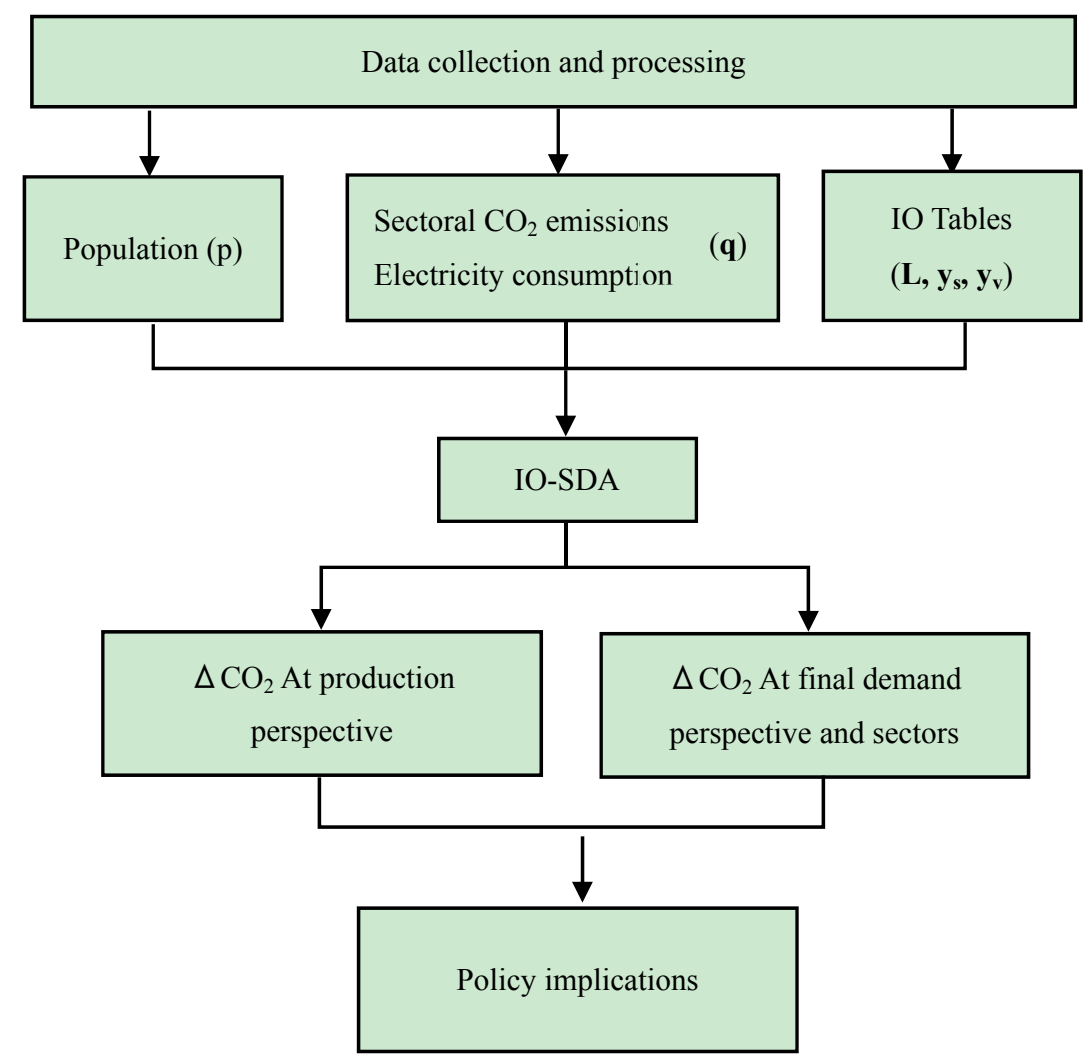

Figure 1. Research framework

\subsection{Generic Input-Output (IO) Analysis}

The IO framework has been conventionally used to describe the interrelationship between different economic sectors in an economy. Its basic formulation contains a system of linear equations where the total output of the system is equal to the amount consumed internally by the system as intermediate consumption plus the amount used by final customers (or final demand such as household and government consumption) (Leontief, 1936; 1986). For an economy with $n$ sectors, $\mathbf{x}$ can denote the $n \times 1$ gross domestic output vector, $\mathbf{y}$ the $n \times 1$ final demand vector and $\mathbf{Z}$ the $n \times \mathrm{x} n$ input-output matrix. In matrix notation, the IO model can be written as follows (Miller \& Blair, 2009):

$$
\mathbf{x}=\mathbf{Z e}+\mathbf{y}
$$


where $\mathbf{e}$ is column vector with all elements having a value of 1 . A denotes the $n \times n$ technology coefficient matrix with elements $a_{i j}\left(a_{i j}=Z_{i j} / x_{j}\right)$ representing the amount of product from the $i^{\text {th }}$ sector needed to produce one unit of output from the $j^{\text {th }}$ sector. Based on this, Equation 1 can be converted as follows:

$$
(\mathbf{I}-\mathbf{A})^{-1} \mathbf{y}=\mathbf{x}
$$

where $\mathbf{I}$ denotes an $n \times n$ identity matrix and $(\mathbf{I}-\mathbf{A})^{-1}$ is the $n \times n$ Leontief inverse matrix $(\mathbf{L})$ which expresses the requirements for an economy's production.

By adding environmental factors into the economic IO model, Environmental Input-Output (EIO) analysis may be used to account for environmental interventions of each sector. This method is discussed in detail in Miller and Blair (2009). The EIO model links environmental interventions with sector production and final demand consumption. Suh (2009) employed this model in accounting for $\mathrm{CO}_{2}$ releases in a supply chain network to conduct sustainability assessment while Tan, Culaba, \& Aviso, 2008; Tan, Ballacillo, Aviso, \& Culaba (2009) applied the EIO for optimizing a multi-regional bioethanol supply chain network with the presence of multiple objectives. Wiedmann and Barrett (2011) used EIO to account for GHG generation embodied in goods and services purchased by Central Government. Recently, H. Nguyen, Aviso, Kojima, \& Tokai (2018a) applied this model to analyze the inter-relationship between economic sectors and water pollution in Vietnam. In this case, $\mathrm{CO}_{2}$ emissions contributed by economic sectors in Vietnam are considered as the environmental intervention. The amount of $\mathrm{CO}_{2}$ emission of each sector is assumed to be proportional to the total output of that sector. Let q represent a $1 \times n$ vector which contains the sectoral pollution intensity. The pollution intensity of a sector is equal to the amount of emissions generated by the sector divided by its gross output. Therefore, the quantity of $\mathrm{CO}_{2}$ emissions can be expressed as follows:

$$
\mathbf{Q}=\mathbf{q} \mathbf{L} \mathbf{y}
$$

where $\mathbf{Q}$ is the total $\mathrm{CO}_{2}$ emission from all sectors.

\subsection{Input-Output Structural Decomposition Analysis (IO-SDA)}

IO-SDA is a method frequently applied to quantify the contribution of various factors to the total changes in economic and environmental flows using IO tables (Hoekstra \& van den Bergh, 2002; Minx et al.; 2011; Xu, Li, Crittenden, \& Chen, 2011). The IO-SDA framework is utilized in this study to analyze the variations of $\mathrm{CO}_{2}$ emissions in categorical periods due to 5 factors including production structure $(\mathbf{L})$, pollution intensity $(\mathbf{q})$, population ( $\mathrm{p})$, consumption structure $\left(\mathbf{y}_{\mathbf{s}}\right)$ and consumption volume $\left(\mathbf{y}_{\mathbf{v}}\right)$.

Production structure is considered as the Leontief inverse matrix (L). The changes in this factor express the changes in input requirement of each sector. Pollution intensity (q) can reflect the improved energy efficiency or technology factor (energy consumption per unit output) when there is less emission per unit of energy output. To differentiate the contributions of various consumption components, final demand, $\mathbf{y}$, is decomposed into three components namely consumption structure, consumption volume and population as follows.

$$
\mathbf{y}=\mathbf{y}_{\mathrm{s}} \mathbf{y}_{\mathrm{v}} \mathrm{p}
$$

where $\mathbf{y}_{\mathbf{s}}$ is a $n \times m$ matrix of consumption structure with $m$ amount of consumption categories (in this study $m=$ 5 (e.g. household, government, investment, export and import)). Assuming that $\mathbf{F}$ is a $n \times m$ matrix of consumption flows, its element, $F_{i d}$, denotes the amount of final demand of category $d$ in the $i^{t h}$ sector. Thus, the consumption structure of final demand category $d$ in response to the $i^{\text {th }}$ sector is expressed as $y_{s}^{i d}=\frac{F_{i d}}{\sum_{i=1}^{n} F_{i d}}$; $\mathbf{y}_{\mathbf{v}}$ is a $1 \times m$ vector of consumption volume, its element, $y_{v}^{d}=\frac{\sum_{i=1}^{n} F_{i d}}{p}$ represents the per capita final demand of category $d$; and $p$ is a scalar value representing the population. Therefore, Equation 4 can be rewritten as:

$$
\mathbf{Q}=p \mathbf{q} \mathbf{L} \mathbf{y}_{\mathbf{s}} \mathbf{y}_{\mathbf{v}}
$$

Over a given time period, any change in $\mathrm{CO}_{2}$ emissions $(\Delta Q)$ in an economy can be indicated by Equation 6 , where the five factors including emission intensity, population, production structure, consumption structure and consumption volume completely account for the increase or decrease in $\mathrm{CO}_{2}$ emissions from the production perspective. Thus, Equation 5 can be written as:

$$
\Delta Q=\Delta p \mathbf{q} \mathbf{L} \mathbf{y}_{\mathbf{s}} \mathbf{y}_{\mathbf{v}}+p \Delta \mathbf{q} \mathbf{L} \mathbf{y}_{\mathbf{s}} \mathbf{y}_{\mathbf{v}}+p \mathbf{q} \Delta \mathbf{L} \mathbf{y}_{\mathbf{s}} \mathbf{y}_{\mathbf{v}}+p \mathbf{q} \mathbf{L} \Delta \mathbf{y}_{\mathbf{s}} \mathbf{y}_{\mathbf{v}}+p \mathbf{q} \mathbf{L} \mathbf{y}_{\mathbf{s}} \Delta \mathbf{y}_{\mathbf{v}}
$$

where $\Delta p, \Delta \mathbf{q}, \Delta \mathbf{L}, \Delta \mathbf{y}_{\mathbf{s}}$ and $\Delta \mathbf{y}_{\mathbf{v}}$ represent the changes of each factor in which each $\Delta$ is calculated when all other 
factors are assumed to be constant. For example, $\Delta \mathbf{y}_{\mathbf{s}}$ is change in consumption structure, and this term $\left(p \mathbf{q} \mathbf{L} \Delta \mathbf{y}_{\mathbf{s}} \mathbf{y}_{\mathbf{v}}\right)$ represents the change of total $\mathrm{CO}_{2}$ emissions resulting from a change in consumption structure with population, $\mathrm{CO}_{2}$ emission intensity, production structure and consumption volume staying constant.

In structural decomposition analysis, it is possible to compare various factors related to any point in time within a study period. According to Dietzenbacher and Los (1998), there are plenty of possible solutions of decomposition. If the number of decomposed factors is $\mathrm{k}$, the number of possible decomposition equations is $\mathrm{k}$ ! (in this case $\mathrm{k}=5$ ). Since the number of decision factors are excessively powerful to compute, this problem can be solved using the average of all possible first-order of decompositions for simplification (Koh et al., 2016). This work applies the structural decomposition analysis method proposed by Koh et al. (2016). For further details, see Appendix.

In consideration of IO-SDA for assessing the changes in $\mathrm{CO}_{2}$ emissions from the final demand perspective, the formulas introduced by Peters (2008) can be applied to allocate the variations in $\mathrm{CO}_{2}$ emissions to the appropriate final demand category $d$ as follows:

$$
\mathbf{Q}_{d}=\mathbf{q} \mathbf{L} \mathbf{y}_{\mathbf{d}}
$$

Based on Equation 7, the changes in $\mathrm{CO}_{2}$ emissions using the consumption perspective, which includes household consumption, government consumption, investment, export and import, can be achieved. Note that the total change in $\mathrm{CO}_{2}$ emissions from consumption (Equation 7) is equal to the change obtained using the production perspective (Equation 6). It can be understood that the changes from production perspective are obtained by analyzing directly the effect of socio-economic factors on the production of all economic sectors. Meanwhile, final demand perspective allows the analysis of changes in $\mathrm{CO}_{2}$ emissions based on changes in final consumption. In fact, the impact of these socio-economic factors on the economy will also be reflected in its GDP (total final demand). For example, any change in population, or production structure among others, is reflected in GDP or final demand categories.

\section{Data Collection}

The neccesary economic data utilized in this work were obtained from Vietnam IO tables for 2000, 2007 and 2011 which were published in the Vietnamese General Statistical Office (GSO) website (GSO, 2003; 2009; 2013). These contained the most recent information available. The 2000 IO table contains 112 sectors while IO tables 2007 and 2011 have 138 sectors. These IO tables were classified and aggregated into 18 main sectors as shown in Table 1. The classification of sectors was based on the classifications indicated for the IO table from GSO and according to the International Standard Industrial Classification version 3 (UN, 2018). Furthermore, these aggregated IO tables of 2007 and 2011 were converted from 2007 and 2011 prices, respectively, into 2000 constant price through the double deflation methods using each sector's producer price index as obtained from the Vietnamese statistical Yearbook (GSO, 2007; 2011). The Vietnamese IO data include five categories of final demand - households, government, investment, exports and imports. An example of the structure of the Vietnamese IO tables was shown in H. Nguyen et al. (2018a).

Table 1. Nomenclature of sectors

\begin{tabular}{cl}
\hline Sector code & Economic sectors \\
\hline 1 & Agriculture, Fishery and Forestry \\
2 & Mining and Quarrying \\
3 & Food, Beverage and Tobacco \\
4 & Textile, Wearing Apparel and Leather Industries \\
5 & Manufacture of Wood and Wood products \\
6 & Manufacture of Paper and Paper Products, Printing and Publishing \\
7 & Manufacture of Industrial Chemicals and petro chemicals \\
8 & Manufacture of Non-metallic Mineral Products \\
9 & Basic Metal Industries \\
10 & Manufacturing of Fabricated Metal Products, Machinery and Equipment \\
11 & Other Manufacturing Industries
\end{tabular}




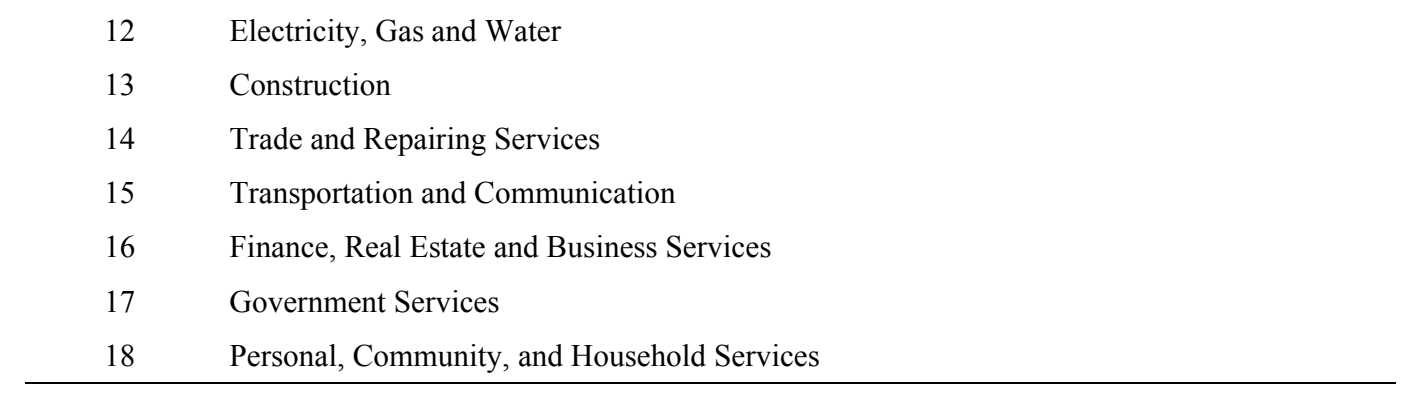

$\mathrm{CO}_{2}$ emissions by sector resulting from fuel combustion in Vietnam are obtained from the International Energy Agency (IEA, 2016). Since electricity produced by power and heat sectors is mainly used by other sectors, $\mathrm{CO}_{2}$ generation from electricity should be allocated to all sectors based on their electricity consumption (Hsu \& Chou, 2000). The data of electricity consumption by sector in Vietnam were obtained from IEA (2017). The sectoral $\mathrm{CO}_{2}$ emissions for different years are shown in Figure 2 while the pollution intensity of sectors is given in Table A.2 in Appendix. The IEA database indicated that Vietnam's energy-related $\mathrm{CO}_{2}$ emissions resulting from economic activities increased by $108 \%$ (from 44,223 thousand tonnes (kt) to 91,969 kt) from 2000 to 2007 and increased by $80.8 \%$ from 2007 to 2011. In the period 2000 - 2007, Sector 11, Sector 15 and Sector 18 were the highest contributors to total direct $\mathrm{CO}_{2}$ emissions (Figure 2). These sectors are considered as energy-intensive sectors. Meanwhile, other sectors which mainly consist of manufacturing sectors such as Sectors 3-10 contributed insignificantly. In contrast, in 2011, not only energy-intensive sectors (Sector 11, 15 and 18), but also manufacturing sectors such as Sector 8 and Sector 4 have high $\mathrm{CO}_{2}$ emissions. The considerable increase in emissions in manufacturing sectors in 2011 was due to Vietnam's accession to the World Trade Organization (WTO) since 2007, which has stimulated international trade between Vietnam and other countries (Le, 2017). Economic sectors, especially manufacturing sectors, were boosted to strongly develop to meet the demand of international trade.

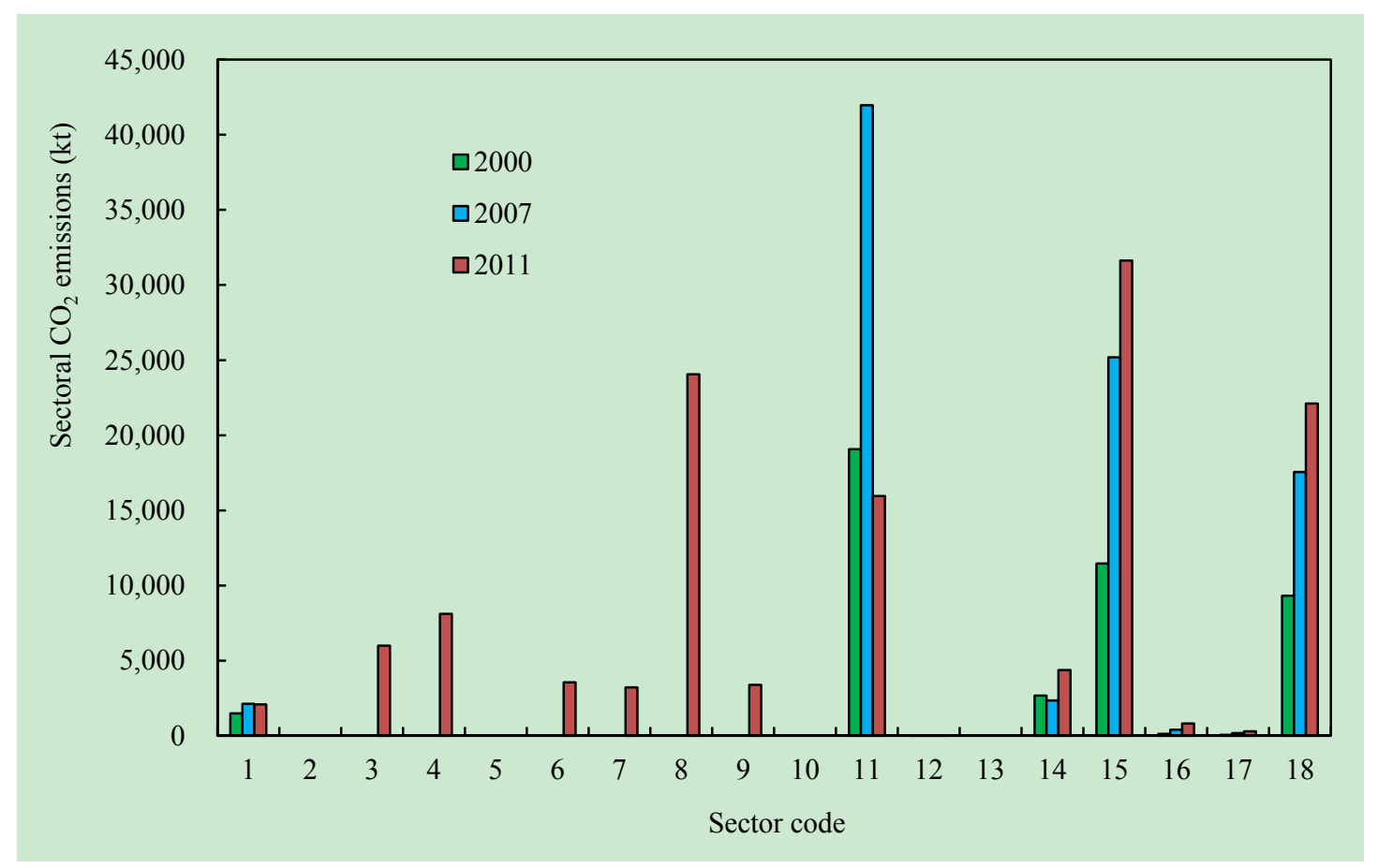

Figure 2. Sectoral $\mathrm{CO}_{2}$ emissions in 2000, 2007 and 2011 (IEA, 2016)

\section{Results}

\subsection{Analysis from the Production Perspective}

Solving Equation 6 using decomposition methods discussed in the Appendix to account for any change in $\mathrm{CO}_{2}$ emissions using the production perspective, the results indicate that in the 11 years from 2000 to 2011, Vietnam's 
energy-related $\mathrm{CO}_{2}$ emissions increased by $188.8 \%(83,495 \mathrm{kt})$. The structural decomposition analysis for the year 2000, 2007 and 2011 reveals how different factors contribute to the change in $\mathrm{CO}_{2}$ emissions (Figure 3). In light of this, three factors: (i) steady growth in population $(24.1 \%, 10,660 \mathrm{kt})$; (ii) consumption structure $(100.5 \%$, $44,423 \mathrm{kt})$; and (iii) consumption volume triggered by per capita consumption $(219.4 \%, 97,029 \mathrm{kt})$ acted as tremendous accelerators of $\mathrm{CO}_{2}$ emission from 2000 until 2011. Meanwhile, the changes in production structure led to a slight decrease in $\mathrm{CO}_{2}$ emissions $(-22.5 \%, 9,927 \mathrm{kt})$, and the changes in improved energy efficiency (pollution intensity) resulted in a $-132.7 \%(58,690 \mathrm{kt})$ decrease. Despite production structure and improved efficiency in production contributing to the decrease in $\mathrm{CO}_{2}$ emissions, consumption structure, consumption volume and population contributes to the sharp increase of emissions. This led to accelerating tendency of $\mathrm{CO}_{2}$ emissions in period 2000-2011. These findings are consistent with the analysis of changes in $\mathrm{CO}_{2}$ emissions and energy consumption from 1986 to 2008 carried out by A. Nguyen (2012).

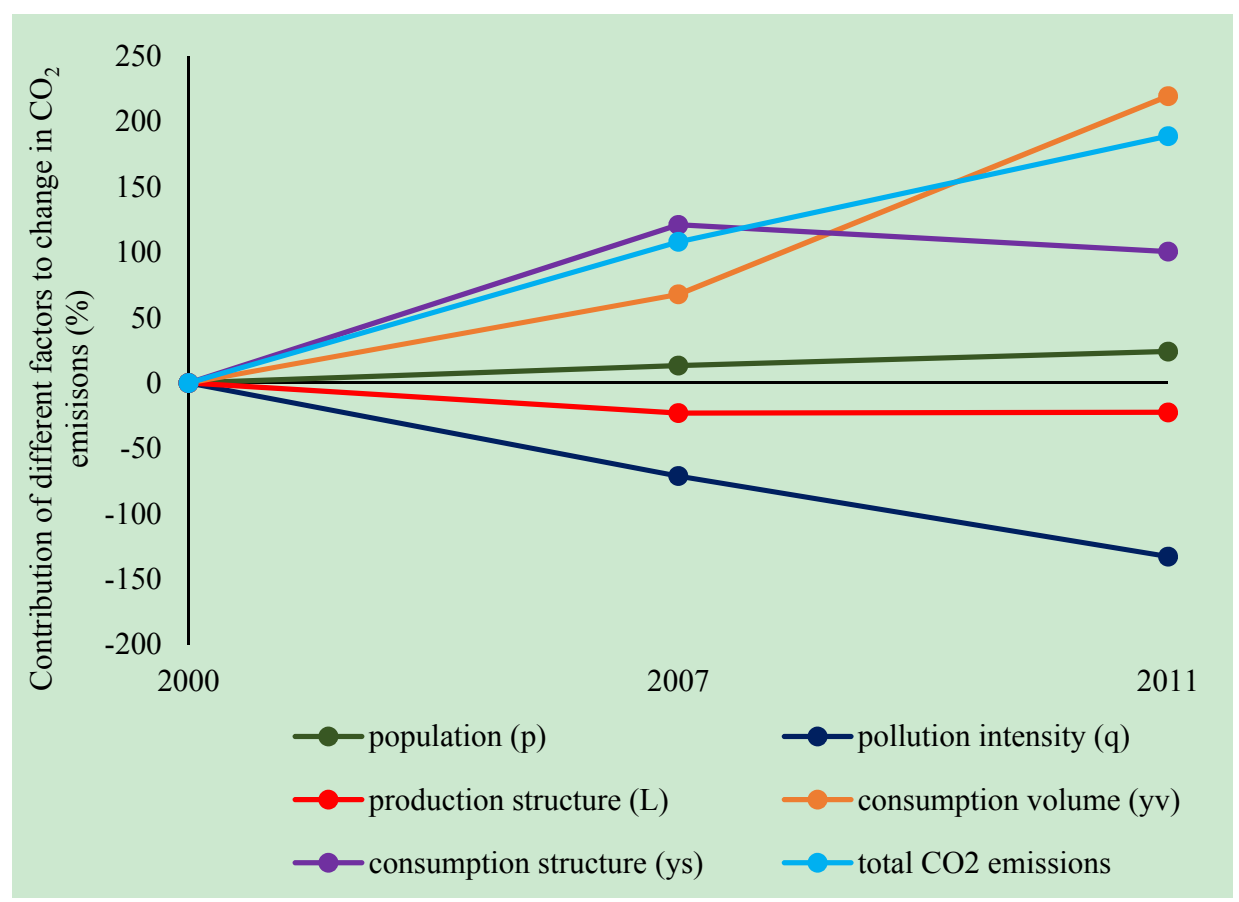

Figure 3. Contributions of driving factors to changes in Vietnamese $\mathrm{CO}_{2}$ emissions between 2000 and 2011

Figure 4 shows which factors dominated within the shorter periods of 2000 - 2007 and 2007 - 2011. During 2000 - 2007, population growth, increased consumption volume and increased consumption structure increased $\mathrm{CO}_{2}$ emissions by $202 \%$ (89,343 kt) $(13.3 \%, 5,894 \mathrm{kt} ; 67.8 \%, 29,982 \mathrm{kt}$; and $120.9 \%, 53,467 \mathrm{kt}$, respectively) (Figure 4). However, production structure $(-23 \%, 10,160 \mathrm{kt})$ and pollution intensity $(-71.1 \%, 31,436 \mathrm{kt})$ were two factors which offset the incremental change in $\mathrm{CO}_{2}$ in the same period. Overall, the $\mathrm{CO}_{2}$ emissions increased significantly by $108 \%(47,747 \mathrm{kt})$ between 2000 and 2007 . In the period of $2007-2011$, population $(10.8 \%$, $4,766 \mathrm{kt})$ and consumption volume $(151.6 \%, 67,047 \mathrm{kt})$ exerted upward influence on $\mathrm{CO}_{2}$. This was offset by an improvement in efficiency $(-61.6 \%, 27,253 \mathrm{kt})$ and consumption structure $(-20.5 \%, 9,044 \mathrm{kt})$, which led to an actual increase in total $\mathrm{CO}_{2}$ generation of $80.8 \%$ (35,748 kt). Meanwhile, changes in production structure remained almost constant. 


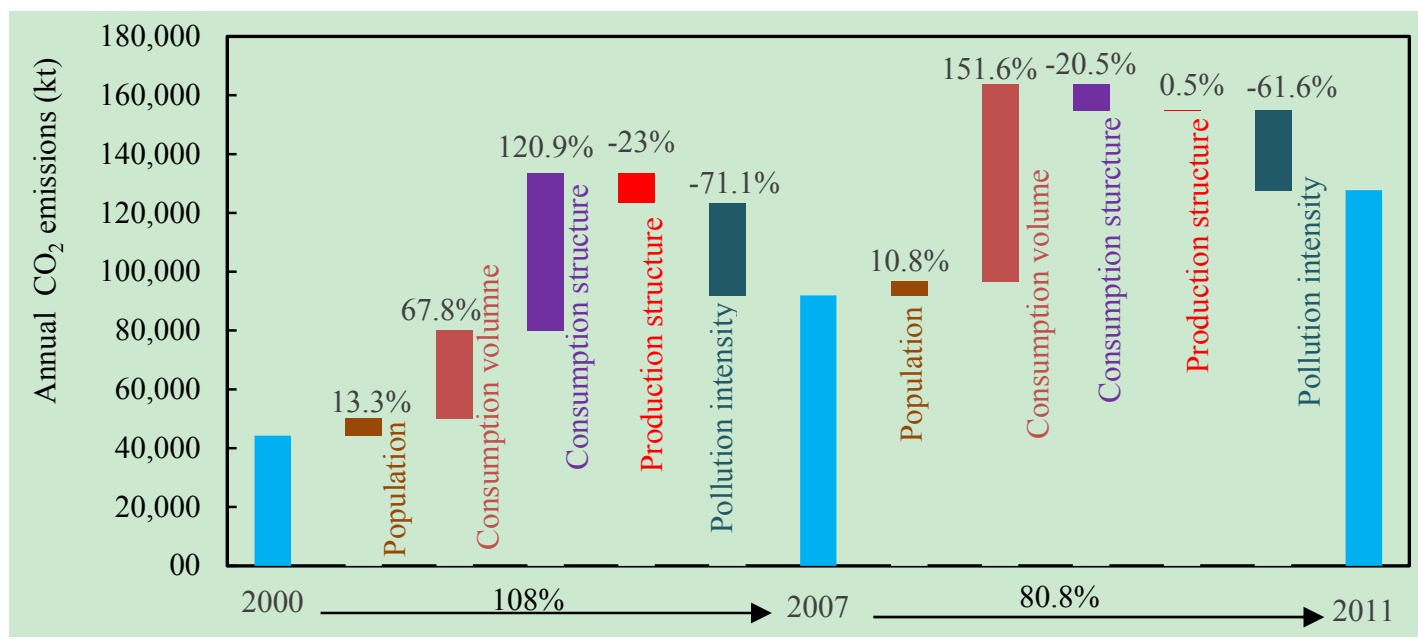

Figure 4. Contributions of different factors to Vietnam's $\mathrm{CO}_{2}$ emission change based on two periods 2000-2007 and 2007-2011

From these results, it can be stated that notable improvement in efficiency for both periods contributes to offsetting the increment in $\mathrm{CO}_{2}$. This was reasoned by Dinh and Lin (2014) and Zimmer et al. (2015). First, the production of Vietnam's economic industries mainly depended on imported oil, meanwhile the international oil prices rose significantly in the $21^{\text {st }}$ century. This urged the implementation of advanced energy-saving and the improvement of energy-efficient technologies (Andrei, 2007). Second, Vietnam shifted from fossil fuel into a fuel mix which increased the consumption of natural gas to partially replace coal. Furthermore, the consumption of biofuel and waste for power generation was also a main contributor-to $\mathrm{CO}_{2}$ emission reduction.

Consumption volume was a main factor contributing to the sharp increase. Meanwhile, the consumption structure varied between two periods. During 2000 - 2007, consumption structure contributes to an increase of $120.9 \%$ while this number decreased to $-20.5 \%$ between 2007 and 2011 . The drastic variation as explained by Le (2017) is that Vietnam's accession to WTO since January 2007 strongly affected trade liberalization and improved market access for the new member country's exports and imports (Le, 2017). As a result, trade activities, especially import, increased sharply during 2007 - 2011, which significantly contributed to the reduction of $\mathrm{CO}_{2}$ emissions. Thus, accession to WTO increased emissions in consumption volume due to an increase of production activities and consumptions but they had positive effect on $\mathrm{CO}_{2}$ mitigation in terms of consumption structure due to the sharp decrease of $\mathrm{CO}_{2}$ in import factor. The next section discusses the allocation of total emissions to different final demand categories.

\subsection{Analysis from the Consumption Perspective}

Analyzing the changes of $\mathrm{CO}_{2}$ emissions from the consumption (final demand) perspective could uncover underlying driving factors in the whole supply chain network (Liu et al., 2012; Wang et al., 2013; Peters, Weber, Guan, \& Hubacek, 2007). In this paper, Equation 7 is used to account for this. The allocation of $\mathrm{CO}_{2}$ emissions into the different final demand categories is shown in Table 2 and analysis results of economic sectors are given in Table 3 and Tables A.3 and A.4 in the Appendix.

Table 2. Contribution of different consumption categories to $\mathrm{CO}_{2}$ emissions (kt)

\begin{tabular}{lll}
\hline \multicolumn{1}{c}{ Period } & 2000-2007 & 2007-2011 \\
Categories & & \\
\hline Household & 29,756 & 27,021 \\
Government & 3,675 & 1,069 \\
Investment & $-3,033$ & 30,385 \\
Export & 23,908 & 46,665 \\
Import & $-8,740$ & $-69,334$ \\
\hline
\end{tabular}


Table 3. Allocation of $\mathrm{CO}_{2}$ emission changes (kt) during 2000 - 2011 by different consumption categories and sectors

\begin{tabular}{cccccc}
\hline Categories & $\begin{array}{c}\text { HHs. } \\
\text { Consumption }\end{array}$ & $\begin{array}{c}\text { Govt. } \\
\text { Consumption }\end{array}$ & Total I & Export & Import \\
\hline 1 & 68 & 6 & 125 & 823 & -434 \\
2 & 0 & 0 & 0 & 0 & 0 \\
3 & 4,707 & 34 & $-2,629$ & 5,614 & $-1,736$ \\
4 & 3,591 & 48 & $-1,503$ & 14,344 & $-8,373$ \\
5 & 0 & 0 & 0 & 0 & 0 \\
6 & 4,474 & 295 & 430 & 4,846 & $-6,485$ \\
7 & 9,346 & 340 & 3,312 & 12,179 & $-21,960$ \\
8 & 7,950 & 325 & 21,240 & 13,662 & $-19,119$ \\
9 & 10,874 & 257 & 22,115 & 20,440 & $-50,305$ \\
10 & 0 & 0 & 0 & 0 & 0 \\
11 & $-15,999$ & $-1,554$ & $-17,529$ & $-12,198$ & 44,162 \\
12 & 11 & 1 & 6 & 13 & -17 \\
13 & 0 & 0 & 0 & 0 & 0 \\
14 & 64 & -47 & -504 & 1,228 & 965 \\
15 & 18,819 & 704 & 1,920 & 9,796 & $-11,069$ \\
16 & 729 & 39 & 96 & 265 & -442 \\
17 & 83 & 145 & 0 & 1 & -1 \\
18 & 12,061 & 4,150 & 273 & -439 & $-3,260$ \\
\hline
\end{tabular}

Changes in household consumption caused 29,765 kt and 27,021 kt increases in $\mathrm{CO}_{2}$ emissions during the first and second period, respectively (Table 2). Changes in household were analyzed by sector during $2000-2011$ and are shown in Table 3 and Figure 5. Meanwhile, the contribution of government to changes in $\mathrm{CO}_{2}$ was not considerable (Figure 6).

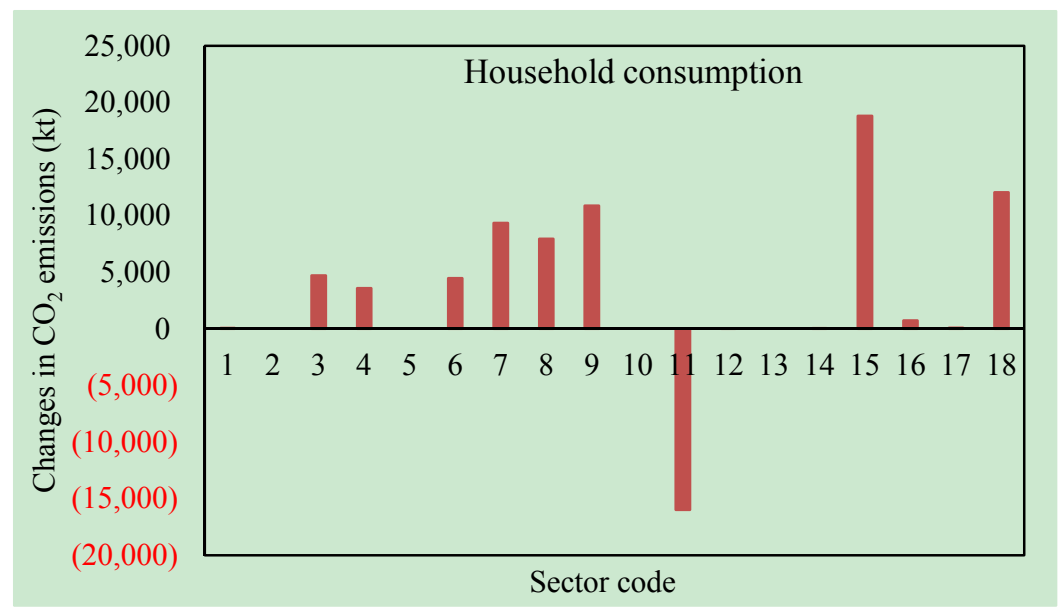

Figure 5. Allocation of $\mathrm{CO}_{2}$ emission changes (kt) during 2000 - 2011 by household consumption 


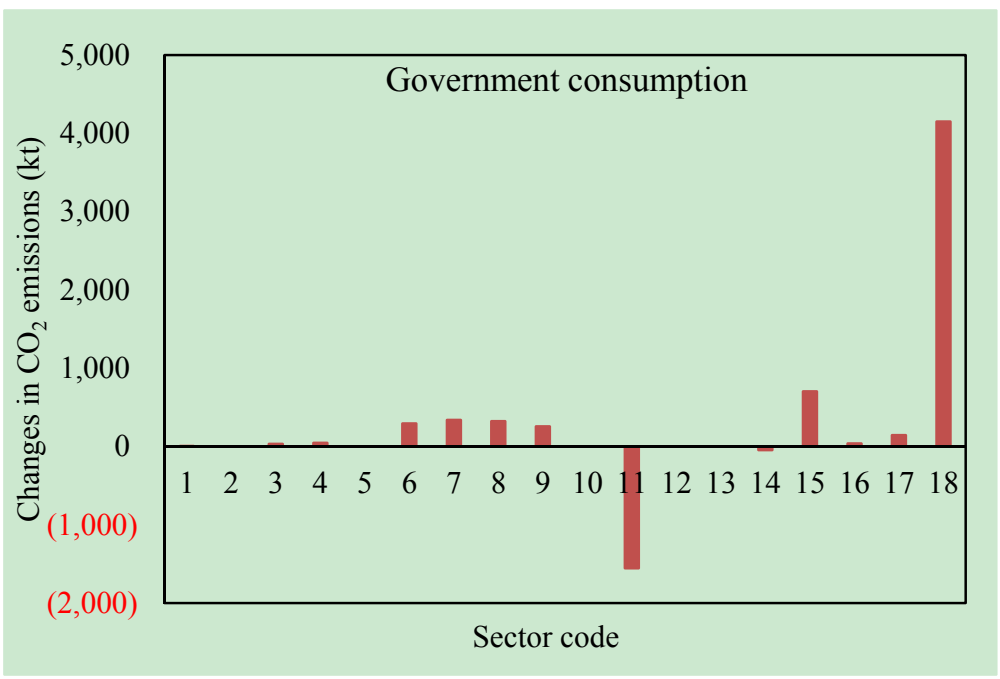

Figure 6. Allocation of $\mathrm{CO}_{2}$ emission changes (kt) during 2000 - 2011 by government consumption

The changes in investment followed an irregular path for both periods. In the first period, there was a slight decrease in $\mathrm{CO}_{2}$ emissions from investment, but it sharply increased up to $30,385 \mathrm{kt}$ in the second period. This was explained that there was an increase in FDI during 2006 - 2010 compared to 2001 - 2005 (Ngo, Dao, H. T. Nguyen, \& Dao, 2017) which was mainly used for the expansion of manufacturing production (Dinh \& Lin, 2014). As a result, $\mathrm{CO}_{2}$ emissions from manufacturing industries sharply changed during 2006 - 2011 (see Figure 1). Figure 7 indicates the increase and decrease in $\mathrm{CO}_{2}$ emissions in various sectors resulting from investment. Under which, Sector 8 (manufacture of non-metallic mineral products, 21,240 kt) and Sector 9 (basic metal industry, 22,115 kt) were the main contributors in the increase of $\mathrm{CO}_{2}$ emissions. In contrast, Sector 11 (Other Manufacturing Industries) was the main sector in the reduction of $\mathrm{CO}_{2}$ emissions $(-17,529 \mathrm{kt})$. These results are consistent with information mentioned by Dinh and Lin (2014). According to Dinh and Lin (2014), the investment in Sectors 8 and 9 resulted in the increase in emissions because these sectors require intensive-energy for their production. Meanwhile, emissions in Sector 11 reduced because investment was used for both economic growth and environmental protection, (e.g. application of cleaner and more efficient production activities and/or end-of-pipe treatment technologies in factories).

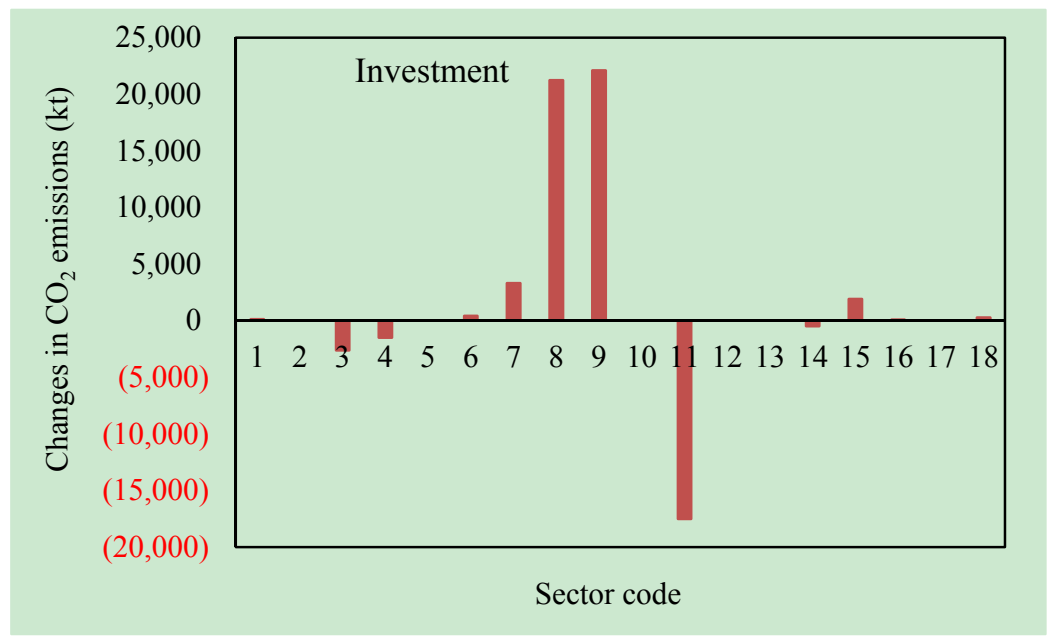

Figure 7. Allocation of $\mathrm{CO}_{2}$ emission changes (kt) during 2000 - 2011 by investment

Export was also a key driving force of $\mathrm{CO}_{2}$ emission incremental change during both periods. Changes in export caused a sharp increase from the first period $(23,908 \mathrm{kt})$ to second period $(46,665 \mathrm{kt})$. The analysis by sector is shown in Figure 8. 


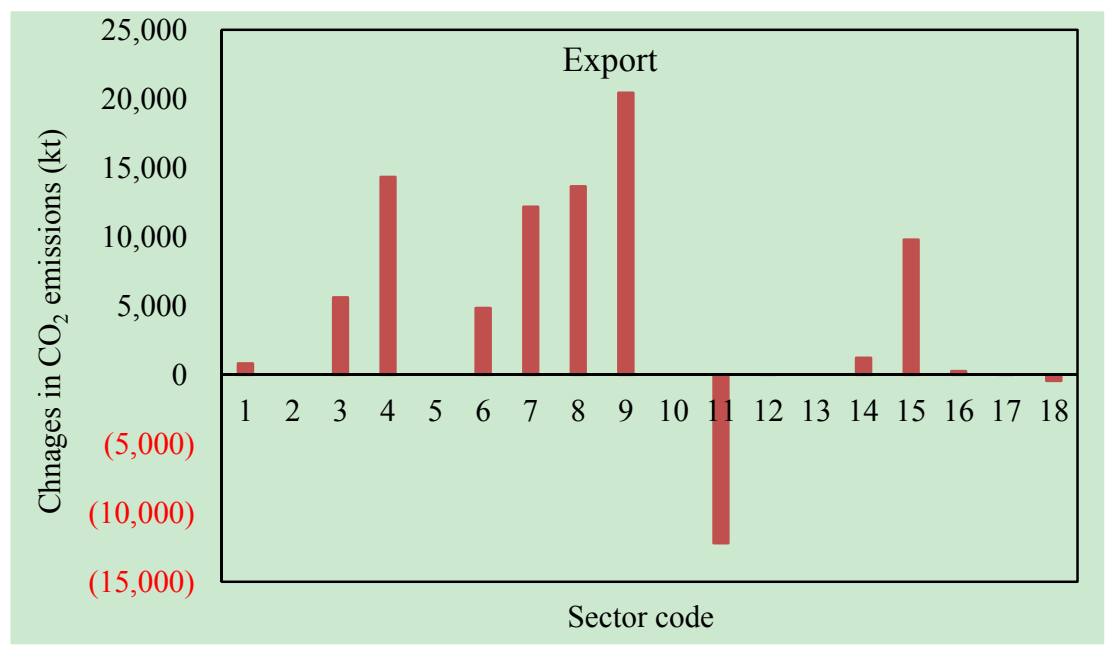

Figure 8. Allocation of $\mathrm{CO}_{2}$ emission changes (kt) during 2000 - 2011 by export

Import activities were main drivers in $\mathrm{CO}_{2}$ reduction with $-8,740 \mathrm{kt}$ during 2000 - 2007 and $-69,334 \mathrm{kt}$ during 2007 - 2011. Since the $\mathrm{CO}_{2}$ emissions in this paper was estimated as production-based emissions, the increase in production of domestic products for different purposes such as household, government and export normally causes the increment in pollution for Vietnam, but the increase in the importation of goods and services produced from other countries may help this country avoid emissions. The analysis by sector in terms of import is given in Figure 9. From these results, it can be stated that the accession to WTO from 2007 helped improve import and export between Vietnam and other countries. This greatly affected the economic development and environmental pollution in Vietnam from the year of 2007 onwards.

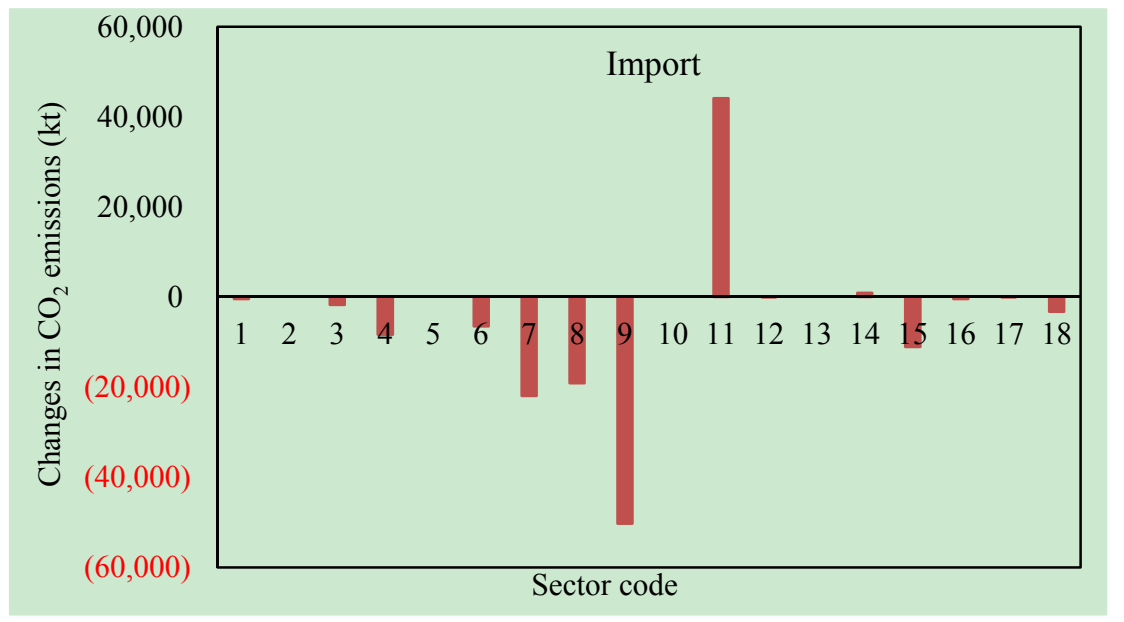

Figure 9. Allocation of $\mathrm{CO}_{2}$ emission changes (kt) during 2000 - 2011 by import

\subsection{Policy Implications for Mitigating $\mathrm{CO}_{2}$ Emissions}

As a result of rapid industrialization and modernization, especially after accession to WTO, the Vietnamese economy has positively prospered through the expansion of manufacturing industries and the increase in international trade activities with other countries. These led to increasing energy consumption induced $\mathrm{CO}_{2}$ emissions. Thus, the appropriate identification of driving factors related to increase in $\mathrm{CO}_{2}$ emissions is significant in developing policies.

\subsubsection{From the Production Perspective}

Using the production perspective, the consumption volume, consumption structure and pollution intensity are the main driving forces which influence $\mathrm{CO}_{2}$ emissions in Vietnam. Meanwhile, population growth, had a small effect on the increase in $\mathrm{CO}_{2}$ release, but the rapid population growth in the future especially in big cities such as 
Hanoi and Ho Chi Minh may affect environmental-social-economic development. Thus, implementing the policies to encourage birth rate reduction is of significance for emission reduction. Pollution intensity or technical factor is a strong factor in offsetting $\mathrm{CO}_{2}$ generation in all other factors considered in this paper. According to KEPA and GreenID (2014), there is still significant potential for further improving energy use efficiency by varying fuel mix use (i.e., increasing natural gas use and decreasing coal and oil uses), replacement of fossil fuels by clean and renewable energy such as wind energy, solar energy and bio-gas, and carbon capture and sequestration. Furthermore, policies for encouraging continued energy conservation should be given. In addition to technology improvement, strong regulations are required to capture other potentials to mitigate emissions through economic structural adjustment and optimization in both production and consumption sides. In the whole observed time period, Vietnam's $\mathrm{CO}_{2}$ emissions were $22 \%$ lower due to improvement in production structure. These emissions due to production structure can be further lowered through increased resource efficiency such as reducing highly pollutive inputs, recycling products and waste.

\subsubsection{From the Consumption Perspective and Sectors}

From deeply analyzing using the consumption perspective, household, investment, export and import are key driving factors to the changes in $\mathrm{CO}_{2}$ emissions. The growth of $\mathrm{CO}_{2}$ emissions relative to household consumption is driven by a combination of increased consumption of urban household and urbanization (DEA, 2017). Therefore, to reduce emissions from household consumption, there is a need to shift structure toward using more environmental friendly products or reducing the use of energy-intensive products (i.e., appliances and electricity).

Investments are important for economic development in Vietnam, but the downside is the increase in emissions from the production of heavy manufacturing such as cement, steel, glass, etc. However, if investments are channeled towards improving the efficiency of technologies or implementing cleaner technologies, Vietnam can further reduce its emissions. These may also stimulate the enterprises toward low- $\mathrm{CO}_{2}$ production-

International trade including import and export has been an important driving force for Vietnam's economic development. Table 2 has shown that trade activities may contribute to the decrease in $\mathrm{CO}_{2}$ emissions by promoting import. However, this may result in high emissions in original countries where products are produced. Thus, to reduce global pollution problem, there is need to import goods from countries that can produce more efficiently. Furthermore, there is a need to optimize trade structures between Vietnam and other countries. Reducing the import of highly-pollutive materials also help reduce emissions for domestic production.

Taking into account $\mathrm{CO}_{2}$ emissions from various economic sectors, it can be seen that Sector 15 (transportation and communication) and Sector 18 (personal, community, and household services) and the manufacturing sectors (Sector 3-11) are main contributors to $\mathrm{CO}_{2}$ emissions in Vietnam. To reduce emissions in Sector 18, there is a need to shift economic structure toward using more environmental friendly goods and services or reducing the consumption of energy-intensive products. To decrease emissions in Sector 15 the most logical option for Vietnam is to invest in traffic infrastructure to develop public transportation and reduce private vehicles. Using energy-efficient vehicles to replace traditional ones is also helpful. For manufacturing sectors (Sector 3-11), the best option to reduce pollution is by using cleaner technologies, improving process efficiency and waste treatment systems, and replacing highly pollutive raw materials with less pollutive inputs.

\section{Conclusions and Recommendations}

This paper uses IO-SDA model to analyze underlying driving forces for the changes in energy-based $\mathrm{CO}_{2}$ emissions in Vietnam during two periods 2000 - 2007 and 2007 - 2011. This model is more useful than traditional SDA methods because it can highlight any change of pollutant resulting from different socio-economic factors at both macro-economic and sectoral levels. This method makes use of available IO tables in 2000, 2007 and 2011 and other socio-economic data to indicate the variation of $\mathrm{CO}_{2}$ emissions contributed by economic activities using both production perspective (technology, production structure, consumption structure, consumption volume and population growth) and final demand perspective (government, household, investment, import and export). Such analysis is helpful for decision makers, manufacturers and relevant partners to know the structural dynamics of $\mathrm{CO}_{2}$ generation. These can be used to formulate effective and sustainable emission mitigation strategies and management protocols for short and long-term plans.

The results from the production perspective indicate that the overall energy-related $\mathrm{CO}_{2}$ emissions in Vietnam from 2000 to 2011 increased by $188.8 \%$ (83,495 kt). Consumption structure and consumption volume were the main drivers responsible for this incremental change in $\mathrm{CO}_{2}$ emissions, while $\mathrm{CO}_{2}$ pollution intensity and production structure were two main factors which offset this increase. However, population growth had a small effect on the increase in $\mathrm{CO}_{2}$ generation during this period, but it may have significant effect if population 
growth rate increased rapidly in the future. From the final demand perspective, household, export and investment are the key drivers responsible for the sharp increase in $\mathrm{CO}_{2}$ emissions between 2000 and 2011, while import factor contributes to the abatement of $\mathrm{CO}_{2}$ emissions. Government had inconsiderable effect on the growth in $\mathrm{CO}_{2}$ emissions. Between these two periods, different factors contributed differently to the increase and decrease in $\mathrm{CO}_{2}$. Consumption structure has the largest variation with an increase of $120.9 \%$ during $2000-2007$ and a decrease of 20.5\% between 2007 and 2011. This was due to the increase in import activities in the second period resulting from the accession to WTO in 2007. In consideration of $\mathrm{CO}_{2}$ changes by sector, Sector 11 (other manufacturing industries), Sector 15 (transportation and communication) and Sector 18 (personal, community, and household services) were energy-intensive sectors which contributed greatly to the total $\mathrm{CO}_{2}$ emissions during 2000-2007. In contrast, between 2007 and 2011, besides the energy-intensive sectors mentioned above, manufacturing sectors such as Sector 9 (basic metal industry,), Sector 8 (manufacture of non-metallic mineral products), Sector 7 (manufacture of industrial chemicals) and Sector 4 (textile, wearing apparel and leather industries) also have high $\mathrm{CO}_{2}$ emissions and strongly impacted the changes in $\mathrm{CO}_{2}$ emissions in this period. These results suggest that the mitigation of domestic $\mathrm{CO}_{2}$ emissions in Vietnam can be obtained by $\mathrm{CO}_{2}$ pollution intensity reduction, structural adjustment and optimization of production and final demand activities. Furthermore, optimizing international trade is greatly significant for the abatement of national and global $\mathrm{CO}_{2}$ generation.

This research is especially developed for the Vietnam context, but the same methods can be easily adapted for analyzing other economies using existing IO table and pollution data. Furthermore, these methods can be applied for analyzing the structural changes of any kind of pollutant induced by various economic sectors, once the data are available. The limitation of this study is that it just focuses on $\mathrm{CO}_{2}$ emissions from energy sectors, while $\mathrm{CO}_{2}$ emissions from remaining sectors are not considered. Future work can develop a model to evaluate the changes in $\mathrm{CO}_{2}$ pollution intensity as the industrial and manufacturing sectors apply more advanced treatment and cleaner technology. Furthermore, a model should be developed in the future to see the effect of reduced birth rate in $\mathrm{CO}_{2}$ emission. In addition, tools for handling data uncertainty can be coupled in this model to result in more robust analysis.

\section{Acknowledgments}

The authors are grateful for the financial support provided by the Japan International Cooperation Agency (JICA) to study and conduct this research.

\section{References}

Andrei, I. (Ed.). (2007). Reasonability of Protocol and Kyoto-type Targets, Climate Change Policy and Economic Growth: A Way Forward to Ensure Both, Margo Thorning (International Council of Capital Formation) and Andrei Illarionov (Institute of Economics Analysis), 1-30.

Aviso, K. B., Tan, R. R., Culaba, A. B., \& Cruz, J. B. (2011). Fuzzy input-output model for optimizing eco-industrial supply chains under water footprint constraints. J. Clean. Prod., 19, 187-196. https://doi.org/10.1016/j.jclepro.2010.09.003

Cansino, J. M., Roman, R., \& Ordóñez, M. (2016). Main drivers of changes in $\mathrm{CO}_{2}$ emissions in the Spanish economy: A structural decomposition analysis. Energy Policy, 89, 150-159. https://doi.org/10.1016/j.enpol.2015.11.020

Cansino, J. M., Sánchez-Braza, A., \& Rodríguez-Arévalo, M. L. (2015). Driving forces of Spain's $\mathrm{CO}_{2}$ emissions: a LMDI decomposition approach. Renew. Sustain. Energy Rev., 48, 749-759. https://doi.org/10.1016/j.rser.2015.04.011

Chen, B., Li, J. S., Zhou, S. L., Yang, Q., \& Chen, G. Q. (2017). GHG emissions embodied in Macao's internal energy consumption and external trade: Driving forces via decomposition analysis. Renewable and Sustainable Energy Reviews. https://doi.org/10.1016/j.rser.2017.10.063

DEA (Danish Energy Agency). (2017). Vietnam Energy Outlook Report 2017. Retrieved January 10, 2018, from https://ens.dk/sites/ens.dk/files/Globalcooperation/Official_docs/Vietnam/vietnam-energy-outlook-report-20 17-eng.pdf

Dietzenbacher, E., \& Los, B. (1998). Structural decomposition techniques: sense and sensitivity. Economic Systems Research, 10, 307-323. https://doi.org/10.1080/09535319800000023

Dinh, L. H., \& Lin, S. M. (2014). $\mathrm{CO}_{2}$ Emissions, Energy Consumption, Economic Growth and FDI in Vietnam. Managing Global Transitions, 12(3), 219-232. 
Fu, B., Wu, M., Che, Y., Wang, M., Huang, Y., \& Bai, Y. (2015). The strategy of a lowcarbon economy based on the STIRPAT and SD models. Acta Ecol. Sin., 35, 76-82. https://doi.org/10.1016/j.chnaes.2015.06.008

GSO (General Statistical Office). (2003). Input-Output: IO of Vietnam Year 2000. Statistical Publishing House: Hanoi; 142-246.

GSO (General Statistical Office). (2007). Statistical Yearbook of Vietnam. Statistical Publishing House: Hanoi.

GSO (General Statistical Office). (2009). Input-Output: IO of Vietnam Year 2007. Statistical Publishing House: Hanoi.

GSO (General Statistical Office). (2011). Statistical Yearbook of Vietnam. Statistical Publishing House: Hanoi.

GSO (General Statistical Office). (2013). Input-output: IO of Vietnam year 2011. Statistical Publishing House: Hanoi.

Guan, D., Hubacek, K., Weber, C. L., Peters, G. P., \& Reiner, D. M. (2008). The drivers of Chinese $\mathrm{CO}_{2}$ emissions from 1980 to 2030. Global Environmental Change Human and Policy Dimensions, 18, 626-634. https://doi.org/10.1016/j.gloenvcha.2008.08.001

Hoekstra, R., \& van den Bergh, J. C. J. M. (2002). Structural decomposition analysis of physical flows in the economy. Environmental and Resource Economics, 23, 357-378. https://doi.org/10.1023/A:1021234216845

Hsu, G. J. Y., \& Chou, F. Y. (2000). Integrated planning for mitigating CO2 emissions in Taiwan: A multiobjective programming approach. Energy Policy, 28(8), 519-523. https://doi.org/10.1016/S0301-4215(00)00006-9

Huang, Y. H., \& Wu, J. H. (2013). Analyzing the driving forces behind $\mathrm{CO}_{2}$ emissions and reduction strategies for energy-intensive sectors in Taiwan, 1996-2006. Energy, 57, 402-411. https://doi.org/10.1016/j.energy.2013.05.030

IEA (International Energy Agency). (2016). $\mathrm{CO}_{2}$ Emissions from Fuel Combustion, OECD/IEA, Paris. Retrieved May 30, 2017, from http://wds.iea.org/wds/pdf/Worldco2_Documentation.pdf

IEA (International Energy Agency). (2017). Retrieved December 12, 2017, from http://www.iea.org/Sankey/\#?c=VietNam\&s=Final consumption

IPCC (Intergovernmental Panel on Climate Change). (2006). IPCC Guidelines for National Greenhouse Gas Inventories.

KEPA and GreenID (Service Center for Development Cooperation \& Green Innovation and Development Centre). (2014). Assessment of policies on GHG mitigation in Vietnam, 1-31. Retrieved April 10, 2017, from https://www.kepa.fi/tiedostot/final_report_vietnam_1marz2014.pdf

Koh, S. C. L., Ibn-Mohammed, T., Acquaye, A., Feng, K., Reaney, I. M., Hubacek, K., Fujii, H., \& Khatab, K. (2016). Drivers of U.S. toxicological footprints trajectory 1998-2013. Scientific Report, 6, 39514. https://doi.org/10.1038/srep39514

Le, A. T. (2017). Effects of WTO accession on Vietnam's trade: The gravity model approach. Publisher: Reprosentralen, University of Oslo. Retrieved January 10, 2018, from http://www.duo.uio.no

Leontief, W. W. (1936). Quantitative input and output relations in the economic systems of the United States. The review of economic statistics, 105-125. https://doi.org/10.2307/1927837

Leontief, W. W. (Ed.). (1986). Input-output economics. Oxford University Press.

Liu, Z., Geng, Y., Lindner, S., Zhao, H., Fujita, T., \& Guan, D. (2012). Embodied energy use in China's industrial sectors. Energy Policy, 49, 751-758. https://doi.org/10.1016/j.enpol.2012.07.016

Maryzin, V. M. (2013). Economic Modernization in Vietnam From Industrialization to Innovation Stage. Journal of Economics and Business, 29(2), 87-106.

Mavromatidis, G., Orehounig, K., Richner, P., \& Carmeliet, J. (2016). A strategy for reducing CO2 emissions from buildings with the Kaya identity e a Swiss energy system analysis and a case study. Energy Policy, 88, 343-354. https://doi.org/10.1016/j.enpol.2015.10.037

Miller, R. E., \& Blair, P. D. (2009). Input-Output Analysis: Foundation and Extensions (2nd ed.). Published in the United States of America by Cambridge University Press, New York. https://doi.org/10.1017/CBO9780511626982

Minx, J. C., Baiocchi, G., Peters, G. P., Weber, C. L., Guan, D., \& Hubacek, K. (2011). A “Carbonizing Dragon”: 
China's fast growing $\mathrm{CO}_{2}$ emissions revisited. Environmental Science \& Technology, 45, 9144-9153. https://doi.org/10.1021/es201497m

MNRE (Ministry of Natural Resources and Environment). (2014). The initial biennial updated report of Viet Nam to the United Nation Framework Convention on climate change. Viet Nam publishing house of nature resources, environment and cartography. MNRE, Ha Noi, 2014. Retrieved March 8, 2017, from http://unfccc.int/resource/docs/natc/vnmbur1.pdf

Ngo, H. P., Dao, H. V., Nguyen, H. T., \& Dao, T. T. T. (2017). Improving quality of foreign direct investment attraction in Vietnam. International Journal of Quality Innovation, 3,7. https://doi.org/10.1186/s40887-017-0016-7

Nguyen, A. T. K. (2012). Structural decomposition analysis of CO2 emission variability in Vietnam during the 1986-2008 period. VNU Journal of Science, Economics and Business, 28(2), 115-123.

Nguyen, H. T., Aviso, K. B., Kojima, N., \& Tokai, A. (2018). Structural analysis of the interrelationship between economic activities and water pollution in Vietnam in the period of 2000 -2011. Clean Techn Environ Policy. https://doi.org/10.1007/s10098-018-1492-8

Nguyen, H. T., Aviso, K. B., Le, D. Q., Kojima, N., \& Tokai, A. (2018). An Input-output linear programming model for mapping low-carbon scenarios for Vietnam - a projection for 2030. Unpublished paper.

Nguyen, N. T., Ha-Duong, M., \& Sandra, G. (2009). The clean development mechanism in Vietnam: potential and limitations. Paper accepted to present at the fourth GMSARN International Conference 2009 "Energy Security and Climate Change: Problems \& Issues in GMS" to be held from 25-27 November 2009 at Ha Long Bay, Vietnam.

Nguyen, T. T. A., \& Ishihara, K. N. (2006a). Analysis of changing hidden energy flow in Vietnam. Energy Policy, 34, 1883-1888. https://doi.org/10.1016/j.enpol.2005.01.011

Nguyen, T. T. A., \& Ishihara, K. N. (2006b). Energy productivity during the years of Doi Moi. Journal of Applied Input-output Analysis, $11 \& 12$.

Peters, G. P. (2008). From production-based to consumption-based national emission inventories. Ecol. Econ., 65, 13-23. https://doi.org/10.1016/j.ecolecon.2007.10.014

Peters, G. P., Weber, C. L., Guan, D., \& Hubacek, K. (2007). China's growing $\mathrm{CO}_{2}$ emissions: a race between increasing consumption and efficiency gains. Environmental Science \& Technology, 41, 5939-5944. https://doi.org/10.1021/es070108f

PricewaterhouseCoopers. (2017). The world in 2050. Retrieved August 21, 2017, from https://www.pwc.com/gx/en/world-2050/assets/pwc-the-world-in-2050-full-report-feb-2017.pdf

Rose, A., \& Casler, S. (1996). Input-output structural decomposition analysis: a critical appraisal. Econ. Syst. Res., 8(1), 33-62. https://doi.org/10.1080/09535319600000003

Rose, A., \& Chen, C. Y. (1991). Source of change in energy use in the US economy, 1972-1982: a structural decomposition analysis. Resour. Energy, 13(1), 1-21. https://doi.org/10.1016/0165-0572(91)90017-W

Shahiduzzaman, M., \& Layton, A. (2017). Decomposition analysis for assessing the United States 2025 emissions target: How big is the challenge? Renewable and Sustainable Reviews, 67, 372-383. https://doi.org/10.1016/j.rser.2016.08.042

Shrestha, R. M., Anandarajah, G., \& Liyanage, M. H. (2009). Factors affecting CO2 emission from the power sector of selected countries in Asia and the Pacific. Energy Policy, 37, 2375-2384. https://doi.org/10.1016/j.enpol.2009.01.032

Shuai, C., Shen, L., Jiao, L., Wu, Y., \& Tan, Y. (2017). Identifying key impact factors on carbon emission: Evidences from panel and time-series data of 125 countries from 1990 to 2011. Applied Energy, 187, 310-325. https://doi.org/10.1016/j.apenergy.2016.11.029

Štreimikienè, D., \& Balezentis, T. (2016). Kaya identity for analysis of the main drivers of GHG emissions and feasibility to implement EU "20-20-20" targets in the Baltic States. Renewable and Sustainable Energy Reviews, 58, 1108-1113. https://doi.org/10.1016/j.rser.2015.12.311

Suh, S. (2009). Handbook of input-output economics in industrial ecology (2nd ed.). Ecology edn. Springer, Berlin. https://doi.org/10.1007/978-1-4020-5737-3

Tan, R. R., Ballacillo, J. B., Aviso, K. B., \& Culaba, A. B. (2009). A fuzzy multi- ple objectives approach to the 
optimization of bioenergy system footprints. Chem Eng Res Des., 87, 1162-1170. https://doi.org/10.1016/j.cherd.2009.04.004

Tan, R. R., Culaba, A. B., \& Aviso, K. B. (2008). A fuzzy linear programming extension of the general matrix-based life cycle model. J Clean Prod., 16, 1358-1367. https://doi.org/10.1016/j.jclepro.2007.06.020

The World Bank. (2010). World Development Report. The World Bank, Washington, DC.

UN (United Nations). (2002). International Standard Industrial Classification of All Economic Activities, Rev.3. (ISIC 3). Retrieved June 12, 2016, from https://unstats.un.org/unsd/cr/registry/regcst.asp?Cl=2

UNFCCC (United Nations Framework Convention on Climate Change). (1998). Retrieved September 30, 2017, from http://unfccc.int/resource/docs/convkp/kpeng.pdf

United Nations Framework Convention on Climate Change (UNFCC) (2015b). Intended Nationally Determined Contribution of Vietnam, 1-11. Retrieved February 8, 2018, from http://www4.unfccc.int/ndcregistry/PublishedDocuments/Viet\%20Nam\%20First/VIETNAM'S\%20INDC.p df

United Nations Framework Convention on Climate Change (UNFCC). (2015a). Adoption of the Paris Agreement, 1-32. Retrieved February 8, 2018, from https://unfccc.int/resource/docs/2015/cop21/eng/109r01.pdf

Wang, C., \& Wang, F. (2015). Structural Decomposition Analysis of Carbon Emissions and Policy Recommendations for Energy Sustainability in Xinjiang. Sustainability, 7, 7548-7567. https://doi.org/10.3390/su7067548

Wang, H., Ang, B. G., \& Bin, S. (2017). A Multi-region Structural Decomposition Analysis of Global CO2 Emission Intensity. Ecol. Econ., 142, 163-176. https://doi.org/10.1016/j.ecolecon.2017.06.023

Wang, X., Huang, K., Yu, Y., Hu, T., \& Xu, Y. (2016). An input-output structural decomposition analysis of changes in sectoral water footprint in China. Ecological Indicators, 69, 26-34. https://doi.org/10.1016/j.ecolind.2016.03.029

Wang, Z., Huang, K., Yang, S., \& Yu, Y. (2013). An input-output approach to evaluate the water footprint and virtual water trade of Beijing, China. J. Clean. Prod., 42(3), 172-179. https://doi.org/10.1016/j.jclepro.2012.11.007

Wang, Z., Yin, F., Zhang, Y., \& Zhang, X. (2012). An empirical research on the influencing factors of regional $\mathrm{CO}_{2}$ emissions: evidence from Beijing city, China. Appl. Energy, 100, 277-284. https://doi.org/10.1016/j.apenergy.2012.05.038

Wei, J., Huang, K., Yang, S., Li, Y., Hu, T., \& Zhang, Y. (2017). Driving forces analysis of energy-related carbon dioxide $\left(\mathrm{CO}_{2}\right)$ emissions in Beijing: an input-output structural decomposition analysis. Journal of Cleaner Production, 163, 58-68. https://doi.org/10.1016/j.jclepro.2016.05.086

Wiedmann, T., \& Barrett, J. (2011). A greenhouse gas footprint analysis of UK Central Government, 1990-2008. Environmental Science \& Policy, 14, 1041-1051. https://doi.org/10.1016/j.envsci.2011.07.005

Xie, S. C. (2014). The driving forces of China's energy use from 1992 to 2010: An empirical study of inputoutput and structural decomposition analysis. Energy Policy, 73, 401-415. https://doi.org/10.1016/j.enpol.2014.05.035

$\mathrm{Xu}, \mathrm{M}$., Li, R., Crittenden, J. C., \& Chen, Y. (2011). $\mathrm{CO}_{2}$ emissions embodied in China's exports from 2002 to 2008: a structural decomposition analysis. Energy Policy, 39, 7381-7388. https://doi.org/10.1016/j.enpol.2011.08.068

Xu, Y., \& Dietzenbacher, E. (2014). A structural decomposition analysis of the emissions embodied in trade. Ecological Economics, 101, 10-20. https://doi.org/10.1016/j.ecolecon.2014.02.015

Zimmer, A., Jakob, M., Steckel, J. C. (2015). What motivates Vietnam to strive for a low-carbon economy? - On the drivers of climate policy in a developing country. Energy for Sustainable Development, 24, 19-32. https://doi.org/10.1016/j.esd.2014.10.003 


\section{Appendix}

\section{Structural decomposition method}

As presented in Methods, the changes of $\mathrm{CO}_{2}$ emissions are decomposed into five terms and each term expresses the contribution of the changing factor to total $\mathrm{CO}_{2}$ emissions. According to Koh et al. (2016), Eq. 6 is rewritten as follows:

$$
\Delta Q=w^{p} \Delta p+w^{q} \Delta q+w^{L} \Delta L+w^{y_{s}} \Delta y_{s}+w^{y_{v}} \Delta y_{v}
$$

where $w^{p}, w^{q}, w^{L}, w^{y_{s}}$ and $w^{y_{v}}$ are called weight or coefficient for each the change of factor ( $\Delta$ factor) population, pollution intensity, production structure, consumption structure and consumption volume, respectively. Due to no unique solution for the decomposition, Dietzenbacher and Los (1998) suggested to use the average of all the $\mathrm{k} !(5 !=120)$ decomposition equations. The calculation of $\Delta$ factor and weight or coefficient were given in detail in Koh et al. (2016). In light with this, assuming that in each given period, the changing factor is calculated from base year ( $\mathrm{t}-1)$ to the target year $(\mathrm{t})$. Therefore, each "w" attached to the $\Delta$ factor in Eq. A.1 can be expressed, for example:

$$
\begin{aligned}
w^{p} \Delta p= & \frac{1}{120}\left[\left(24 \cdot \Delta p \cdot q_{(t-1)} \cdot L_{(t-1)} \cdot y_{s(t-1)} \cdot y_{v(t-1)}\right)+\right. \\
& \left(6 \cdot \Delta p \cdot q \cdot L_{(t-1)} \cdot y_{s(t-1)} \cdot y_{v(t-1)}\right)+ \\
& \left(6 \cdot \Delta p \cdot q_{(t-1)} \cdot L_{(t)} \cdot y_{s(t-1)} \cdot y_{v(t-1)}\right)+ \\
& \left(6 \cdot \Delta p \cdot q_{(t-1)} \cdot L_{(t-1)} \cdot y_{s(t)} \cdot y_{v(t-1)}\right)+ \\
& \left(6 \cdot \Delta p \cdot q_{(t-1)} \cdot L_{(t-1)} \cdot y_{s(t-1)} \cdot y_{v(t)}\right)+ \\
& \left(4 \cdot \Delta p \cdot q_{(t)} \cdot L_{(t)} \cdot y_{s(t-1)} \cdot y_{v(t-1)}\right)+ \\
& \left(4 \cdot \Delta p \cdot q_{(t)} \cdot L_{(t-1)} \cdot y_{s(t)} \cdot y_{v(t-1)}\right)+ \\
& \left(4 \cdot \Delta p \cdot q_{(t)} \cdot L_{(t-1)} \cdot y_{s(t-1)} \cdot y_{v(t)}\right)+ \\
& \left(4 \cdot \Delta p \cdot q_{(t-1)} \cdot L_{(t)} \cdot y_{s(t)} \cdot y_{v(t-1)}\right)+ \\
& \left(4 . \Delta p \cdot q_{(t-1)} \cdot L_{(t)} \cdot y_{s(t-1)} \cdot y_{v(t)}\right)+ \\
& \left(4 \cdot \Delta p \cdot q_{(t-1)} \cdot L_{(t)} \cdot y_{s(t)} \cdot y_{v(t)}\right)+ \\
& \left(6 \cdot \Delta p \cdot q_{(t-1)} \cdot L_{(t)} \cdot y_{s(t)} \cdot y_{v(t)}\right)+ \\
& \left(6 \cdot \Delta p \cdot q_{(t)} \cdot L_{(t-1)} \cdot y_{s(t)} \cdot y_{v(t)}\right)+ \\
& \left(6 \cdot \Delta p \cdot q_{(t)} \cdot L_{(t)} \cdot y_{s(t-1)} \cdot y_{v(t)}\right)+ \\
& \left(6 . \Delta p \cdot q_{(t)} \cdot L_{(t)} \cdot y_{s(t)} \cdot y_{v(t-1)}\right)+ \\
& \left.\left(24 \cdot \Delta p \cdot q_{(t)} \cdot L_{(t)} \cdot y_{s(t)} \cdot y_{v(t)}\right)\right]
\end{aligned}
$$

\begin{tabular}{|c|c|c|c|c|}
\hline \multicolumn{4}{|c|}{ Subscript for the components in the of $\Delta$ factors } & \multirow{3}{*}{ weight } \\
\hline \multicolumn{4}{|c|}{ Order of factors } & \\
\hline first & second & third & fourth & \\
\hline $\mathrm{t}-1$ & $\mathrm{t}-1$ & $\mathrm{t}-1$ & $\mathrm{t}-1$ & 24 \\
\hline $\mathrm{t}$ & $\mathrm{t}-1$ & $\mathrm{t}-1$ & $\mathrm{t}-1$ & \multirow{4}{*}{6} \\
\hline $\mathrm{t}-1$ & $\mathrm{t}$ & $\mathrm{t}-1$ & $\mathrm{t}-1$ & \\
\hline $\mathrm{t}-1$ & $\mathrm{t}-1$ & $\mathrm{t}$ & $\mathrm{t}-1$ & \\
\hline $\mathrm{t}-1$ & $\mathrm{t}-1$ & $\mathrm{t}-1$ & $\mathrm{t}$ & \\
\hline $\mathrm{t}$ & $\mathrm{t}$ & $\mathrm{t}-1$ & $\mathrm{t}-1$ & \multirow{3}{*}{4} \\
\hline $\mathrm{t}$ & $\mathrm{t}-1$ & $\mathrm{t}$ & $\mathrm{t}-1$ & \\
\hline $\mathrm{t}$ & $\mathrm{t}-1$ & $\mathrm{t}-1$ & $\mathrm{t}$ & \\
\hline
\end{tabular}

Similarly, the other terms can be obtained using Table A.1

Table A. 1 Subscripts for the components of $\Delta$ factors and their weights. 


\begin{tabular}{ccccc}
$\mathrm{t}-1$ & $\mathrm{t}$ & $\mathrm{t}$ & $\mathrm{t}-1$ & \\
$\mathrm{t}-1$ & $\mathrm{t}$ & $\mathrm{t}-1$ & $\mathrm{t}$ & \\
$\mathrm{t}-1$ & $\mathrm{t}-1$ & $\mathrm{t}$ & $\mathrm{t}$ & \\
\hline $\mathrm{t}-1$ & $\mathrm{t}$ & $\mathrm{t}$ & $\mathrm{t}$ & \\
$\mathrm{t}$ & $\mathrm{t}-1$ & $\mathrm{t}$ & $\mathrm{t}$ & $\mathbf{6}$ \\
$\mathrm{t}$ & $\mathrm{t}$ & $\mathrm{t}-1$ & $\mathrm{t}$ & \\
$\mathrm{t}$ & $\mathrm{t}$ & $\mathrm{t}$ & $\mathrm{t}-1$ & $\mathbf{2 4}$ \\
\hline $\mathrm{t}$ & $\mathrm{t}$ & $\mathrm{t}$ & $\mathrm{t}$ &
\end{tabular}

Table A.2 Sectoral pollution intensity (IEA, 2016)

\begin{tabular}{|c|c|c|c|}
\hline \multirow{2}{*}{ Sector code } & \multicolumn{3}{|c|}{$\mathbf{q}\left(\mathrm{kgCO}_{2} /\right.$ million $\left.\mathrm{VND}\right)$} \\
\hline & 2000 & 2007 & 2011 \\
\hline 1 & 9.196 & 9.064 & 6.443 \\
\hline 2 & 0.000 & 0.000 & 0.000 \\
\hline 3 & 0.000 & 0.000 & 13.256 \\
\hline 4 & 0.000 & 0.000 & 32.043 \\
\hline 5 & 0.000 & 0.000 & 0.000 \\
\hline 6 & 0.000 & 0.000 & 107.767 \\
\hline 7 & 0.000 & 0.000 & 23.804 \\
\hline 8 & 0.000 & 0.000 & 283.077 \\
\hline 9 & 0.000 & 0.000 & 58.349 \\
\hline 10 & 0.000 & 0.000 & 0.000 \\
\hline 11 & 917.003 & 512.650 & 102.207 \\
\hline 12 & 0.202 & 0.180 & 0.181 \\
\hline 13 & 0.000 & 0.000 & 0.000 \\
\hline 14 & 31.664 & 17.696 & 16.974 \\
\hline 15 & 402.866 & 151.956 & 98.525 \\
\hline 16 & 2.990 & 4.122 & 3.350 \\
\hline 17 & 2.990 & 5.038 & 4.375 \\
\hline 18 & 115.645 & 254.782 & 217.159 \\
\hline
\end{tabular}

Table A.3 Contribution of different final demand categories to $\mathrm{CO}_{2}$ emissions (kt) during 2000-2007

\begin{tabular}{cccccc}
\hline Categories & Household & Government & Investment & Export & Import \\
\hline 1 & 352 & 12 & 133 & 838 & -702 \\
2 & 0 & 0 & 0 & 0 & 0 \\
3 & 0 & 0 & 0 & 0 & 0 \\
4 & 0 & 0 & 0 & 0 & 0 \\
5 & 0 & 0 & 0 & 0 & 0 \\
6 & 0 & 0 & 0 & 0 & 0 \\
7 & 0 & 0 & 0 & 0 & 0 \\
8 & 0 & 0 & 0 & 0 & 0 \\
9 & 0 & 0 & 0 & 0 & 0
\end{tabular}




\begin{tabular}{cccccc}
10 & 0 & 0 & 0 & 0 & 0 \\
11 & 6505 & -516 & -7891 & 20537 & 4250 \\
12 & 10 & 0 & 2 & 5 & -10 \\
13 & 0 & 0 & 0 & 0 & 0 \\
14 & -732 & -34 & -57 & -467 & 968 \\
15 & 15196 & 755 & 4594 & 4364 & -11175 \\
16 & 317 & 21 & 56 & 55 & -170 \\
17 & 24 & 91 & 0 & 0 & -1 \\
18 & 8083 & 3346 & 130 & -1423 & -1900 \\
\hline Sum & 29,756 & 3,675 & $-3,033$ & 23,908 & $-8,740$ \\
\hline
\end{tabular}

Table A. 4 Contribution of different final demand categories to $\mathrm{CO}_{2}$ emissions (kt) during 2007-2011

\begin{tabular}{cccccc}
\hline Categories code & Household & Government & Investment & Export & Import \\
\hline 1 & -284 & -5 & -8 & -15 & 268 \\
2 & 0 & 0 & 0 & 0 & 0 \\
3 & 4707 & 34 & -2629 & 5614 & -1736 \\
4 & 3591 & 48 & -1503 & 14344 & -8373 \\
5 & 0 & 0 & 0 & 0 & 0 \\
6 & 4474 & 295 & 430 & 4846 & -6485 \\
7 & 9346 & 340 & 3312 & 12179 & -21960 \\
8 & 7950 & 325 & 21240 & 13662 & -19119 \\
9 & 10874 & 257 & 22115 & 20440 & -50305 \\
10 & 0 & 0 & 0 & 0 & 0 \\
11 & -22505 & -1037 & -9638 & -32735 & 39912 \\
12 & 1 & 0 & 4 & 8 & -8 \\
13 & 0 & 0 & 0 & 0 & 0 \\
14 & 795 & -13 & -447 & 1695 & -3 \\
15 & 3623 & -51 & -2674 & 5432 & 106 \\
16 & 412 & 18 & 40 & 210 & -272 \\
17 & 59 & 54 & 0 & 0 & 0 \\
18 & 3978 & 804 & 143 & 985 & -1359 \\
\hline Sum & 27,021 & 1,069 & 30,385 & 46,665 & $-69,334$ \\
\hline
\end{tabular}

\section{Copyrights}

Copyright for this article is retained by the author(s), with first publication rights granted to the journal.

This is an open-access article distributed under the terms and conditions of the Creative Commons Attribution license (http://creativecommons.org/licenses/by/4.0/). 